\title{
professional direeciory
}

Space reserved for Certified Consulting Meteorologists only. For rates apply to:

Executive Director, AMERICAN METEOROLOGICAL SOCIETY, 45 Beacon St., Boston, Mass. 02108

\section{A. H. GLENN AND ASSOCIATES}

ALFRED H. GLENN

Certified Consulting Meteorologist

Consultants in Meteorology and Oceanography

Registered Engineers in Louisiana and Texas

New Orleans Lakefront Airport, New Orleans, La. 70126:

504-241-2222

3927 Essex Lane, Houston, Tex. 77027: 713-621-3500

Cable Address: GLENN, New Orleans

NORTHEAST WEATHER SERVICE, INC.

JOHN E. WALLACE

JOHN P. MURPHY

Certified Consulting Meteorologists

Specializing in Operational Forecasts

131A Great Road

Bedford, Massachusetts 01730

617-275-8860 TWX 710-326-0799

WEATHER CORPORATION OF AMERICA

JAMES B. HARRINGTON, Ph.D

Certified Consulting Meteorologist

Operational Forecasts and Research Studies for Gas and Electric Utilities ... Construction and Design ... Environmental and

Stack Emission Problems ... Legal and Insurance ... Radio and Television

611 Olive Street, St. Louis, Missouri 63101

Phone: (314) 42i-4737

Cable: Weather, St. Louis

NORTH AMERICAN

WEATHER CONSULTANTS

ROBERT D. ELLIOTT

EINAR L, HOVIND

JOHN T. WALSER

\section{Certified Consulting Meteorologists}

Weather Modification, Environmental and Air Pollution

Field Studies, Weather and Marine Forecasting, Clima-

tology, and Applied Research.

Teletype: 910-334-118

Santa Barbara Municipal Airport, Goleta, Calif. 93017

METEOROLOGY RESEARCH, INC.

N. L. HALLANGER, WILLIAM B. MORELAND

Certified Consulting Meteorologists

Industrial Meteorology - Air Pollution Surveys

Field Investigations - Instrumentation

P.O. Box 637

464 West Woodbury Rd.

Altadena, Calif. 91001

213-791-1901
MURRAY AND TRETTEL, INCORPORATED

JOHN R. MURRAY

DENNIS W. TRETTEL

Certified Consulting Meteorologists

Operational Forecasts, Environmental Studies, Forensic Meteorology, Research Programs.

414 West Frontage Road, Northfield, Illinois 60093 312-446-7800

WEATHER SERVICES, INC.

A Subsidiary of Northeast Weather Service

PETER R. LEAVITT

Certified Consulting Meteorologist

Specializing in Pollution Studies, Statistical Research,

Forensic Meteorology and Expert Testimony

131A Great Road

Bedford, Massachusetts 01730

617-275-8862 TWX 710-321-0305

LEO ALPERT, Ph.D.

Certified Consulting Meteorologist

4122 Cobblestone Place

Durham, North Carolina 27707

919-489-6479

WALLACE E. HOWELL, Sc.D.

Certified Consulting Meteorologist

RFD 3 Box 400

Golden, Colorado 80401

303-277-9125

VINCENT J. SCHAEFER, Sc.D.

\section{Certified Consulting Meteorologist}

Research Consultant

R. D. 3, Box 36, Schermerhorn Road

Schenectady, New York 12306

EXpress 3-8978

518-393-8978 


\section{professional direetiory}

Space reserved for Certified Consulting Meteorologists only. For rates apply to:

Executive Director, AMERiCAN MEteOROlOGiCAL SOCIETy, 45 Beacon St., Boston, Mass. 02108

\section{THE WALTER A. BOHAN COMPANY}

WALTER A. BOHAN, DIRECTOR

\section{Certified Consulting Meteorologist}

Programs in Satellite Meteorology

Applied Research and Visual Communications

2026 Oakton Street, Park Ridge, Illinois 60068 312-825-3677

\section{METRO MONITORING SERVICES}

ERWIN K. KAUPER

Certified Consulting Meteorologist

Environmental Impact and Site Surveys.

Air Pollution Field Studies. Diffusion Analysis.

Weather and Air Quality Forecasting.

Air Pollution Monitoring Instrumentation.

274 East Rowland Avenue, Covina, CA 91723

213-332-8411

\section{E. BREWSTER BUXTON}

\section{Certified Consulting Meteorologist}

Aviation-Engineering-Research

Box 322, Congress Street

Morrisville, Vermont 05661

802-888-4566

\section{RICHARD E. CALE}

\section{Certified Consulting Meteorologist}

Environmental Research Applications

Aviation Weather Investigations

Planning Services

P.O. Box 352, Cerritos, California 90701

213-926-6149

R. ROBERT RAPP, Ph.D.

\section{Certified Consulting Meteorologist}

4752-B La Villa Marina

Marina del Rey, California 90291

213-823-8808
WEATHER SCIENCE, INC.

D. RAY BOOKER, PRESIDENT

Certified Consulting Meteorologist

Environmental Data Systems

Environmental Data Services

Weather Modification

P.O. Box FF

Norman, Oklahoma 73069

405-329-5263 or 329-7007

\section{LOREN W. CROW}

\section{Certified Consulting Meteorologist}

2422 South Downing Street

Denver, Colorado 80210

303-722-8665

or 756-3971

SIDNEY R. FRANK . . . GROUP SIDNEY R. FRANK, PRESIDENT

Certified Consulting Meteorologist

General Consulting for Industry and Government

Environmental Research \& Development Programs

Pollution Analyses-Theoretical and Operational

1500 Cecil Cook Place

Santa Barbara Municipal Airport

FAA Building 805-964-4477

Home: 805-965-7540

\section{CIC-ATMOSPHERIC TECHNOLOGY}

(formerly associated with ESD, Sierra Research Corporation)

\section{Certified Consulting Meteorologist}

RALPH PAPANIA, JR.

Weather modification operations and evaluation studies-cloud physics-research radar meteorology-environmental impact studies-cloud modeling applications-airborne instrumentation.

P. O. Box 3007, Boulder, Colorado 80303

(303) $443-0384$

TWX: 910-940-3444

OCEANROUTES, INC.

JOHN D. PLOETZ

\section{Certified Consulting Meteorologist}

Consultants in Meteorology and Oceanography

Operational Forecasts for the Marine Industry

Optimum Ship Routing

1534 Page Mill Road

Palo Alto, California 94304

$$
\text { TWX TELEX }
$$

910-373-1175 345-540
Stanford Industrial Park $\begin{array}{cl}\text { CABLE } & \text { TELEPHONE } \\ \text { OCEANROU } & \end{array}$ 


\section{ppolessional dipectopy}

Space reserved for Certified Consulting Meteorologists only. For rates apply to:

Executive Director, AMERICAN METEOROLOGICAL SOCIETy, 45 Beacon St., Boston, Mass. 02108

INSTITUTE FOR STORM RESEARCH

at the University of St. Thomas

JOHN C. FREEMAN, DIRECTOR OF RESEARCH

JOSEPH L. GOLDMAN, ASSOCIATE DIRECTOR OF RESEARCH

\section{Certified Consulting Meteorologists}

Research in theoretical and applied meteorology, oceanography, mathematics

4104 Mt. Vernon, Houston, Texas 77006

713-529-4891 Telex 762-771

AEROVIRONMENT INC.

PAUL B. MAC CREADY JR., PH.D., PRESIDENT

\section{Certified Consulting Meteorologist}

Air quality observations and projections-freeways, airports, industrial. Consulting; programs; instrumentation: air data systems, acoustic radar. Diffusion, tracing, modeling. Weather modification. Aerodynamics.

660 South Arroyo Parkway

Pasadena, California 91105

213-449-4392

\section{HALES AND CO.}

Environmental Consultants

J. VERN HALES, PH.D.

\section{Certified Consulting Meteorologist}

Air and Water Quality, Environmental Impact Studies,

Field Programs, Remote Sensing, Atmospheric Physics

66 Brookmead Rd., Wayne, Pa. 19087

215-687-2330

\section{BERNARD $\mathrm{H}$. DeWITT \& ASSOCIATES}

Certified Consulting Meteorologist

Consultants in Meteorology \& Aviation Safety

Aviation-Industrial-Government
343 S. Main Street

Ann Arbor, Michigan 48108

313-769-4944

Detroit Office 313-862-1765

Floyd Pearson

528 Victoria Square

Brighton, Michigan 48116

313-227-5290

\section{TEMPO_GE'S CENTER FOR ADVANCED} STUDIES

EDWARD J. TSCHUPP

Certified Consulting Meteorologist

Environmental Research-Meteorology, Hydrology,

Environmental Impact Statements, Technology

Assessments, Model Development, Systems Analysis

777-14th Street N.W.

Washington, D.C. 20005

Drawer QQ

(202) 637-4500

Santa Barbara, Cal. 93102 (805) 965-0551

\section{W. BOYNTON BECKWITH}

\section{Certified Consulting Meteorologist}

111 So. Baybrook Dr., 413

Palatine, Illinois 60067

312-991-0609

(Office) 312-952-6301

\section{TRC-THE RESEARCH CORPORATION of New England}

NORMAN E. BOWNE

GEORGE F. COLLINS

\section{Certified Consulting Meteorologists}

Environmental Scientists and Registered Professional EngineersApplied Research, Engineering, Consulting-Diffusion Meteorology \& Oceanography-Site Surveys-Environmental Impact ReportsLaboratory Services

125 Silas Deane Highway

Wethersfield, Conn. 06109

203-563-143

\section{EUGENe BUELL, Ph.D., P.E.}

Certified Consulting Meteorologist

Kaman Sciences Corporation

1700 Garden of the Gods Road

Colorado Springs, Colo., 80907

303-473-5880

\section{OSCAR TENENBAUM ASSOCIATES}

\section{OSCAR TENENBAUM}

Certified Consulting Meteorologist

Consultant and Research Services in MeteorologyClimatology-Hydrology-Statistics

Investigation and Expert Testimony in

Aviation, Industry, Insurance, Law

39 Bellevue St., Newton, Mass. 02158

Residence: 617-244-0253

JOSEPH A. BROWNE

Certified Consulting Meteorologist

AVIATION-ENGINEERING-RESEARCH

109 Wyatt Road

Garden City, New York 11530

516-742-7397 


\section{prolessional dipectory}

Space reserved for Certified Consulting Meteorologists only. For rates apply to:

Executive Director, AMERICAN METEOROLOGICAL SOCIETY, 45 Beacon St., Boston, Mass. 02108

ENVIRONMENTAL RESEARCH \& TECHNOLOCY, INC.

DAVID B. SPIEGLER, MGR. AIRMAP OPERATIONS

Certified Consulting Meteorologist

- Air Monitoring Analysis and Prediction (AIRMAP®) Systems

- Total Environmental Impact Reports

- Diffusion Modeling and Analysis

- Remote sensing of atmosphere and earth

429 Marrett Road, Lexington, Massachusetts 02173

(617) 861-1490
BALL BROTHERS RESEARCH CORP.

GEORGE E. McVEHIL

Certified Consulting Meteorologist

Air Quality and Meteorological Consulting and Monitoring Services, Environmental Data Collection Systems.

P. O. Box 1062, Boulder, Colorado 80302

Telephone 303-441-4592 


\section{protessional directory}

Space reserved for Members only. For rates apply to:

Executive Director, AMERICAN MeteorologiCAL SOCIETY, 45 Beacon St., Boston, Mass. 02108

\section{ALLEN WEATHER CORPORATION}

Meteorologists-Oceanographers

5207 Wisconsin Ave., N.W.

Washington, D.C. 20015

EMerson 3-7221

Cable: ALWEX WADC

\section{WEATHER ENGINEERING CORPORATION OF CANADA, LTD.}

P.O. Box 2060,

315 Dorval Avenue,

Dorval 780, Quebec, Canada.

514-636-0293

\section{ATMOSPHERICS INCORPORATED}

Operational Weather Modification and Cloud Physics Research Weather Radar and Meteorological Systems Applications Airborne and Ground Based Particulate Measurements

5652 E. Dayton Ave., Fresno, California 93727 209-291-5575

INTERNATIONAL WEATHER CORPORATION WALTER F. ZELTMANN, PRESIDENT

Consultant Meteorologists . . . Oceanography

Forecasts ... Statistical Surveys ... Legal and Insurance

P. O. Box 176, Bay Ridge Station, Brooklyn, N. Y. 11220

212-854-0300

SOUTHEAST WEATHER CONSULTANTS, INC. Consultants For Research, Aviation \& Industry

AVMETS *

Specializing in Programming Jet Minimum Cost Cruise Control Flight Planning For Air Carriers and Business Jets

Southern Aero Building P.O. Box 20637

Atlanta Airport Branch, Atlanta, Georgia 30320

404-761-6991

- Aviation Meteorological Service

\section{DeNARDO \& McFARLAND}

Weather Services, Inc.

Municipal, Industrial and Aviation Forecasts; Atmospheric and Climatological Research Utilizing Computer Facilities

TWX 710-794-4804 412-462-6464

Allegheny County Airport, West Mifflin, Pennsylvania 15122

NATIONAL WEATHER CORPORATION WORLD-WIDE WEATHER SERVICES

Forecasting-Flight Planning-Data Analysis-Surveys-Displays

Hangar Twelve, Newark Airport, Newark, N.J. 07114 201-624-8110

Orange County Airport

Santa Ana, Calif. 92707

213-776-5507

Hangar D

Westchester County Airport

White Plains, N.Y. 10601

914-428-6500

\section{METEOROLOGY INTERNATIONAL}

INCORPORATED

Technologies in the Analysis and Prediction of Physically and Operationally Significant Variabilities in the Atmosphere and Oceans, Satellite Meteorology, Circulation Dynamics, Computer Systems Applications

P. O. Box 349

419 Webster Street, Monterey, California 93940 408-372-5173

WEATHER TRENDS INTERNATIONAL, LTD.

Specializing in Long-Range Forecasts, Weather/Marketing Research \& Promotional Weather Services in North America and Europe

565 Fifth Ave., N.Y., N.Y. 10017 (212) MU 2-4280

European HQ: London

\section{GENERAL WEATHER CENTER}

Directed by Lyle E. Brosché.

Effective Long and Short Range Specialized Forecasts, and Consulting, for Business and Industry. Excellent Client References.

527 Fisher Building, Detroit, Michigan 48202

313-871-3511 TWX 810-221-1287 
prolessional direeciory

Space reserved for Members only. For rates apply to:

Executive Director, AMERICAN METEOROLOGiCAL SOCIETY, 45 Beacon St., Boston, Mass. 02108

METRONICS ASSOCIATES, INC.

W. A. PERKINS, PRESIDENT P. A. LEIGHTON, BD. CHMN. S. W. GRINNELL, L. M. VAUGHAN

Environmental Services ... Atmospheric Research

FP Air Tracer Systems ... Rotorod Samplers

Stanford Industrial Park 3201 Porter Drive

415-493-5632 Palo Alto, California 94304

\section{BENDIX COMMERCIAL SERVICE CORP.}

Marine Science Services

ROBERT A. RAGUSO, MANAGER

Optimum Ship Routing - Ocean Weather Forecasts - Marine Operations Consulting

P. O. Box 2205, South Hackensack, New Jersey 07606

(212) 947-9000 or (201) 288-1550

TWX: 710-990-6114 Telex: 134-318 Cable: BEXMARSERV

DAMES \& MOORE

Consultants in the Environmental and Applied Earth Sciences

Services in Meteorology

Diffusion Studies - Regional Planning for Air Quality - Air Quality Monitoring - Atmospheric Heat Sink Studies - Nuclear Industry

Safety Reports - Industrial Effects on Air Quality

Offices in 31 Principal Cities Throughout the World

CONTROL DATA CORPORATION

Meteorology Department, Research Division

Consulting Services

Assessment of air pollution potential; diffusion modelling - Design of air quality sampling and meteorological networks - Site surveys - Climatological and statistical analyses - Data processing systems

612-853-3595

P.O. Box 1249

Minneapolis, Minnesota 55440

\section{ROBERT S. BUSH}

\section{Consulting Professional Meteorologist}

7910 S.W. 52nd Avenue

Miami, Florida 33143

305-666-4406

\section{WEATHER SURVEYS}

CONRAD B. GOSSET, Forensic Meteorologist

Specializing in investigations for

Law Firms and Insurance Companies

The County Trust Building, Pleasantville, N.Y. 10570

914-769-1350

\section{GULF COAST WEATHER SERVICE}

Commercial Section of

WTVT Television Weather Service

Serving individuals and industry since 1961

$\begin{array}{lr}\text { Roy Leep } & \text { Tampa, Florida } 33622 \\ \text { Director } & 813-876-3592\end{array}$

\section{ENVIRONMENTAL WEATHER SERVICE}

A Service of WFLA, Inc.

Legal - Insurance - Pollution Research - Aviation Industry • Agricultural Forecast - Marine
P. O. Box 1410
Tampa, Florida 33601
Paul Catoe
813-229-7781
George Wooten
Patrick Moore

\section{GEOMET, INCORPORATED}

GEORGE H. MILLY, Ph.D., PRESIDENT

Air pollution analysis, modelling and monitoring; Environmental data systems; weather modification studies; research and operations; instrumentation.

50 Monroe Street

Rockville, Maryland 20850

2814-A Metropolitan Place

301-762-5820

California 91767

714-593-1318

NORTHWEST ENVIRONMENTAL

TECHNOLOGY LABORATORIES, INC.

WILLIAM T. KREISS, Ph.D., PRESIDENT

WILLIAM G. TANK, Director of Technical Services

Air Pollution Monitoring . . E Environmental Impact Statements ... Climatological Studies and Analyses ... Transport and Diffusion Modeling ... . Fog Dispersal Systems ... Instrumentation ... Applied Research

300-120th Ave. N.E., Bldg. Two, Suite 108

Bellevue, Washington 98005 (Seattle Area)

$206-455-3570$ 


\section{protessional directory}

Space reserved for Members only. For rates apply to:

Executive Director, AMERICAN METEOROLOGICAL SOCIETY, 45 Beacon St., Boston, Mass. 02108

\section{LEONARD G. PARDUE}

Consulting Meteorologist

Florida Specialist Since 1948

- Weather Investigations for Law Firms

- Expert Testimony

- Staff Meteorologist, Radio WIOD

$305-888-5434$

641 Falcon Avenue Miami Springs, Fla. 33166

NATIONAL CLIMATIC SERVICES, INC. ROBERT O. WEEDFALL, PRESIDENT

Valley Stagnation Potential and Inversion Assessments . . . Land Use Planning re Air Pollution and Water Resources ... Associated with Other Former NOAA State Climatologists . . .
Post Office Box 741

Morgantown, W. Va. 26505

304-599-4671 or Ag Eng'g. Bldg., WVU Morgantown, W. Va. 26506 304-293-5031
STEARNS-ROGER, INC.

\section{COMPLETE ENVIRONMENTAL SERVICES}

Environmental impact statements . . Pollutant emission, air quality \& water quality monitoring . . . Dispersion estimates ... Ecological consulting ... Meteorological field studies \& consulting services. Contact

ENVIRONMENTAL SCIENCES DIVISION

(303) 758-1122 P.O. Box 5888, Denver, Colorado 80217

C. W. THORNTHWAITE ASSOCIATES

WILLIAM J. SUPERIOR, PRESIDENT

Research and Field Studies

Sensors and Systems

Publications in Climatology

Route 1, Centerton

Elmer, New Jersey 08318

609-358-2350

\section{ACCU-WEATHER}

Weather Forecasting ... Climatological Data \& Surveys ... Specialized weather information ... Over a decade of service to business, government, the professions.

Joel N. Myers, Director

Ellint Abrams, Associate

1164 Smithfield Street

814-237-0309 237-5801

State College, Pa. 16801

\section{CENTRAL WEATHER SERVICE}

over a quarter of a century of experience

EARL S. FINCKLE, PRESIDENT

Consulting Meteorologists

Radio Weathercasting Experts, Commodity Weather Specialists

Aviation, Business and Industry, Government, Forensic Meteorology

Executive Office Building, Pal Waukee Airport

Wheeling, Illinois 60090

312-537-5920 TWX 910-651-2091

\section{MIDWEST WEATHER SERVICE}

Div. Commodity News Services, Inc.

Specializing in operational forecasts and consulting to industry, government media, aviation and agriculture; legal investigations and expert testimony.

1600 Genesee Street

Kansas City, Mo. 64102

816-471-0212

\section{LOCKHEED ELECTRONICS COMPANY/}

AEROSPACE SYSTEMS DIVISION

GERALD L. BARGER, PH.D.

JACK F. PARIS, PH.D.

Consulting Professional Meteorologists

Applied Research in - Statistical Climatology - Environmental Impact - Remote Sensing - Weather-Crop Modeling - Planning and Design Assistance

16811 El Camino Real, Houston, Texas 77058

Dr. Ken Bentley, Director, Science Applications-713-488-0080 


\section{Announcing AMS Publication of}

\section{MONTHLY WEATHER REVIEW}

beginning with Volume 102, No. 1, January 1974. (Formerly published by the National Oceanic and Atmospheric Administration.)

Under the editorship of Chester W. Newton, the Monthly Weather Review will continue its basic emphases on the meteorological topics of weather observation, analysis and forecasting, and instrumentation. Gradual implementation, however, of certain new publication policies is contemplated, especially as they affect the interrelationship between the Journal of Applied Meteorology and the Monthly Weather Review. For further information the reader is referred to the August 1973 issue of the Bulletin of the American Meteorological Society.

Manuscripts for the two departments of the Monthly Weather Review (Articles and Notes or Correspondence) should be submitted to Dr. Chester W. Newton, Editor, Monthly Weather Review, National Center for Atmospheric Research, P. O. Box 3000, Boulder, Colo. 80303 [phone (303)494-5151]. Authors may be members or nonmembers of the Society, and of any nationality, but only manuscripts in the English language can be accepted. Reference should be made to current issues of the Journal of the Atmospheric Sciences, Journal of Applied Meteorology, or Journal of Physical Oceanography for guidance in the preparation of papers.

Authors' institutions will be requested to pay a publication charge of $\$ 60$ per page, in conformance with the current rate for all Society journals, and in accord with the common practice of other scientific and technical societies.

The Monthly Weather Review will be available on a calendar year, subscription-only basis at an annual rate of $\$ 60$ ( $\$ 20$ to AMS members). The single issue price will be $\$ 6$ (\$3 to AMS members).

\section{American Meteorological Society \\ 45 Beacon St., Boston, Mass. 02108}

